Working Together 



\section{Working Together}

COLleCtive ACTION, THE

COMMONS, AND MULTIPLE

METHODS IN PRACTICE

Amy R. Poteete

Marco A. Janssen

Elinor Ostrom

P R I N C E T O N U N I VERS I T Y PRES S

PRINCETON A N D OXFOR D 
Copyright (C 2010 by Princeton University Press

Published by Princeton University Press, 41 William Street, Princeton, New Jersey 08540 In the United Kingdom: Princeton University Press, 6 Oxford Street, Woodstock, Oxfordshire OX20 1TW

press.princeton.edu

All Rights Reserved

Library of Congress Cataloging-in-Publication Data

Poteete, Amy R., 1968-

Working together : collective action, the commons, and multiple methods in practice / Amy R. Poteete, Marco A. Janssen, and Elinor Ostrom.

p. $\mathrm{cm}$.

Includes bibliographical references and index.

ISBN 978-0-691-14603-4 (hardcover : alk. paper) — ISBN 978-0-691-14604-1

(pbk. : alk. paper) 1. Commons-Management-Methodology. 2. Global commonsManagement-Methodology. 3. Natural resources, Communal-ManagementMethodology. I. Janssen, Marco, 1969- II. Ostrom, Elinor. III. Title.

HD1286.P75 2010

$333.2-\mathrm{dc} 22$

British Library Cataloging-in-Publication Data is available

This book has been composed in Sabon

Printed on acid-free paper. $\infty$

Printed in the United States of America

$\begin{array}{llllllllll}10 & 9 & 8 & 7 & 6 & 5 & 4 & 3 & 2 & 1\end{array}$ 
The authors thank many colleagues from all parts of the world who have actively participated in the research efforts described herein. This book would not have been possible without their thoughtful challenges, hard work, and insightful analyses. 
